\title{
THE PROCESS OF ESTABLISHING THE HUNGARIAN TELEVISION
}

\author{
RESOLUTION, FAILURE, NEW RESOLUTION
}

\author{
Péter Rajcsányi \\ Institute of Foreign Relations \\ kapussors@gmail.com
}

\begin{abstract}
The study discloses the secretly held facts of the establishment of Hungarian Television. It analyses the four-year-long process, including fiascos of political decisions, infighting in governmental economic and political organizations, financial aspects, as well as personal conflicts and battles. It discusses the factors leading to the original resolution of establishing Hungarian Television and also the factors contributing to the failure of the resolution. Beyond showing the role and activities of the Television Department itself, the article presents the peculiarities of Hungarian Television stemming from the changes sweeping the Hungarian political, economic and social life between 1952 and 1957.
\end{abstract}

Keywords: Hungarian Television, Hungarian Radio and Television, 1956 October revolution, television, reprisals, history of Hungarian Television, television programme structure

\section{Introduction}

For several decades a generalized view has been maintained that television in the Eastern European countries was simply a tool of propaganda under state and party control. An inherent element of this view has been that television of all those countries followed the same pattern. Therefore, most of the studies dealing with the televisions of the Eastern European countries focused on the changes in the communication systems after $1990 .{ }^{1}$

The original documents for the early years of Hungarian Television were declared secret, kept under tight control in the Radio and Television archive. Some of them, mainly related to the 1956 October revolution, were destroyed. While the Radio Archive has in operation ever since Hungarian Radio restarted after WWII, the Archive Section of Hungarian Television was established only in early 1957 as part of the Film and Documentation Department. Although television began regular broadcasting in February 1956, live broadcasts, which started a few weeks after the arrival of the Pye mobile unit in February 1957, were not recorded. Hungarian Television could not afford to order tele-recording equipment. Unfortunately, it did not use the American kinescope technique - mainly because of the shortage of 16 $\mathrm{mm}$ and $35 \mathrm{~mm}$ cameras and the high price of imported film. The short films produced in 1955-1957 were lost due to the negligence of the Archive Section following 1957 or they were deliberately destroyed as products of "counterrevolutionary" persons and removed from Hungarian Television. Such procedures were "everyday practice" in Hungarian Radio during the reprisal process. Previously recorded reports, products of the dismissed employees were banned from broadcasting "forever" and some of them were even destroyed. The performance of very popular actors, 
actresses, singers and musicians were prohibited on stage, on TV or radio. The original written documents could only be accessed when they were catalogued after 2010. A portion of the documents were available in the National Archives but the overwhelming majority of them could be researched in the Radio and Television Archive after receiving permission from MTVA (Media Services and Support Trust Fund). The resolutions and minutes of the meetings of the decision-making organs of MDP and HSWP as well as those of the Ministerial Council, ministries and the factories involved provided additional significant information. Special reports on radio and television could be found in the Historical Archive of the State Security Services. Articles, news, reports in the contemporary daily press and the Hungarian Movie Newsreel service helped to fill in gaps created by the elimination of several original documents. However, even in contemporary television publications there were errors (e.g. the published television program announced an evening broadcast which was postponed in the last minute by the television leadership and was broadcast only two weeks later within a broader program. Later publications always referred to the first, deficient one). Beyond a critical approach to the archived material, the information "batches" stemming from different sources enable a certain "cross-examination" in of the pertinence of the documents. One of the important problems and tasks of this archive research was that the decisions of the high-level political organs as well as the leading bodies of the Radio complex covered both radio and television in the same document. Each document had to be evaluated carefully to separate what referred to television. Critical evaluation was needed in respect to the publications, which appeared in the period of 1960-1990 and later, as they contained distortion about the sporadically mentioned researched period as well.

Recent studies have shown the multicoloured nature of Eastern European "socialist" television. ${ }^{2}$ They came to the conclusion that television was not only a transmitter sending messages of the government but a vivid organ providing entertainment, knowledge, culture, news and pictures of international events for the public. ${ }^{3}$ Television had been a symbol of the social, cultural and technical development both in the West and the East. ${ }^{4}$ Those studies, however, deal with small fragments from Hungarian Television and mainly material after the mid-sixties. ${ }^{5}$

\section{Why are the Early Years of the Hungarian Television Special?}

The peculiarities of the establishment of television are related to and are the consequences of the changes sweeping the Hungarian political, economic and social life between 1952 and 1957 . The original decision to establish Hungarian television was made in December 1952 under the guidance of Mátyás Rákosi, then omnipotent party leader and prime minister. While the power of the ruling MDP (Hungarian Workers Party) seemed to be intact, many problems existed and elements of a larger storm were brewing. Society began to feel the consequences of overheated heavy industrialisation and diminishing agricultural production due to collectivisation. Production decisions were largely based on political will, neglecting not only the real needs of the population but in many cases the real capabilities of production. Autarky prevailed and foreign trade with capitalist countries was curtailed. From 1949, several former leaders of the democratic change in Hungary had been removed from their positions, were jailed or even unlawfully executed. Any criticisms of the regime's actions were immediately suppressed. Those who raised doubts about the chosen course of development were detained by the growing security forces, the ÁVH (State Protection Authority). The press and the Hungarian radio controlled by the Party did not dare to talk of the real situation in the country but mainly repeated the propaganda messages of the Party and the government. Frequent changes were carried out in the second echelon of political and economic leaders which created not only uncertainty but also administrative chaos and delays in the implementation of decisions. The ruling elite, and so Hungary as a whole, "enjoyed" the military, political and economic support of the Soviet Union. However, the price to be paid for the Soviet liberation of Hungary from the German Nazi and Hungarian fascist rule became more and more oppressive for the public. The indignities included the deportation of tens of thousands for forced labour in Siberia, the neglect by the Soviet Union of the Hungarian territorial request regarding Transylvania, the expelling of Hungarians from Czechoslovakia (obviously approved by Stalin), the 
permanent presence of Soviet troops in the country, the (supposedly free) exploitation of the Hungarian uranium and bauxite resources by the Soviet Union, the enforcement of Soviet rules and ideology in the everyday life of Hungary (in the military, in the culture, etc.). The dependence of Hungary on the Soviet Union was too much, too burdensome for most of the Hungarians. It not only created a physical burden but hurt their national and personal pride. Even powerful cadres on different levels of the government tried to resist the arrogance and incompetence of the Soviet advisors embedded in the Hungarian administration.

Under these circumstances, the establishment of Hungarian television was a relatively small project. Its significance should, however, not be underestimated for three reasons. First of all, the political leadership regarded television as an even more powerful tool than the existing press and radio for convincing the people that the country was developing into an advanced socialist state. Secondly, its development could be connected to many elements of Hungarian industry and the military and could, up to a certain degree, provide entertainment for the public. Television was a significant symbol of the virility of Hungarian modernisation. Thirdly, its role was to show that Hungary is following the Soviet Union and not lagging behind the other Eastern European countries or Western Europe. The "follow the Soviet Union" approach was very much the driving force behind many actions of the Hungarian political leadership and permeated their way of thinking. ${ }^{6}$ For a researcher, the process of the establishment of Hungarian television shows all the key issues of that period in a condensed manner.

Only six months after the Political Committee of the Party decided on the establishment of television, in May 1953 the Hungarian political leadership was admonished by Moscow that the drastic fall of the standard of living threatened the political stability in Hungary and corrections should be made urgently. The Soviet leadership worried about the stability of Hungary, a key country bordering both Yugoslavia (with which the Soviet Union still had a tense relationship) and Austria where the Soviet military presence (along with that of the other victorious powers) was a sensitive issue that hindered the signing of a peace treaty. Then, as a significant step of the destalinization process, the party leader Rákosi was removed as prime minister and replaced by Imre Nagy, former minister of agriculture. The step carried far-reaching messages and had international and domestic consequences. As Rákosi used to call himself openly "Stalin's best pupil," the unlawful acts carried out in Hungary became directly associated with him. So the Hungarian public expected his complete removal from the political life. In relation to media, the most significant step of the Nagy-government was the creation a new Information Office to counterbalance the media influence of the Party apparatus under Rákosi. The Information Office was actively involved in the development of television. Remaining as party leader, Rákosi resisted other elements of the destalinization process initiated by Moscow. He hindered the rehabilitation $^{7}$ of the executed and jailed persons, worked against Imre Nagy and his economic policy, did not make any move toward reconciliation with Yugoslavia, etc. When the Soviet leadership decided in 1955 to return to the accelerated development of heavy and military industry, Rákosi felt that the time was ripe for his return to the helm in Hungary. With the tacit support of the Soviet leadership and with the active support of the majority of the Hungarian party leaders, he managed to remove Imre Nagy from all government positions and even from the Party itself. The Central Committee of MDP made the final decision on April 14, 1955. The reform process came to a sudden halt. Nevertheless, these events had revealed a crack in the supposedly unified political leadership and showed that the created system was not as solid as it seemed to be. At the same time, all these things contributed to the strengthening of public hope that change might happen. Such hope was reinforced by Krushchev's secret speech at the 20th Party Congress of the CPSU whose main points became almost immediately known by the Hungarian public. A stronger destalinization process was needed in Hungary, too. But Rákosi for his own personal interests tried to resist it or at least tried to slow it down.

Then in June 1955, Krushchev announced the need of reconciliation with Tito's Yugoslavia. This was particularly significant for Hungary and for Rákosi himself. Before the Stalin-Tito split, Hungary had built up close friendly ties with Yugoslavia, which were abruptly broken by Rákosi following Stalin's break with Tito. In an effort to dissociate himself from the mistrust associated with a Yugoslav friendship Rákosi initiated his biggest show trial in which the former interior minister Rajk was accused of being Tito's spy. The execution of Rajk and several co-workers in 1951 were directly associated with Rákosi by the Hungarian public. The event was one of the cornerstones of Rákosi's rule. The Soviet reconciliation undermined that power base. So Rákosi found it impossible to make any move toward a 
Hungarian - Yugoslav reconciliation. Both the need to renew Hungarian-Yugoslav relations by condemning Stalin's break, and the need to rehabilite the executed Rajk shattered the pillars of Rákosi's power.

However public sentiment condemned him and his closest associates for delaying the reconciliation and for many other actions, economic failures, and first of all for the ÁVH (State Protection Authority, i.e. security service) terror. His actions became inexcusable and his power became irretrievable. The Soviet leadership forced Rákosi to resign, but mistakenly imposed Ernő Gerö, one of Rákosi's closest allies as the new head of the Party. The ambivalent messages emanating from Moscow created uncertainty in the ruling elite. Those in the top positions were unable to find the "main line" which they could follow. Others who had been removed from power, jailed, and then released from prison in 1954 or later, tried to revive some elements of the more democratic conditions prevailing in 1947-1948. A clear signal of breaking with Rakosi was the reburial of Rajk and other unlawfully executed political and military leaders on October 6th, 1956.

Under these circumstances, as the higher-level authorities exercised less influence over the development of television, the relative power of the Television Department increased. It commenced to broadcast programmes in accordance with the plan elaborated by the Department and formally approved by the Radio Collegium. The actual programme structure was determined by the Television Department. Although the technical capabilities curtailed the program assortment, the Television Department broadcast several short films (with Zoltán Kodály, Aladár Rácz, Mari Törőcsik, Yehudi Menuhin, etc.); excerpts from football matches; a newsreel service (at the beginning the official theatre movie newsreels then its own newsreels); and films of Hungarian theatre performances. It used the Hungarian-made mobile unit for live test broadcasts. However, it avoided direct political propaganda programs. The only real action of political nature was the broadcast of "Soha többé!" (Never again), a short film ${ }^{8}$ about the fate of László Rajk and the other executed leaders and about their reburial.

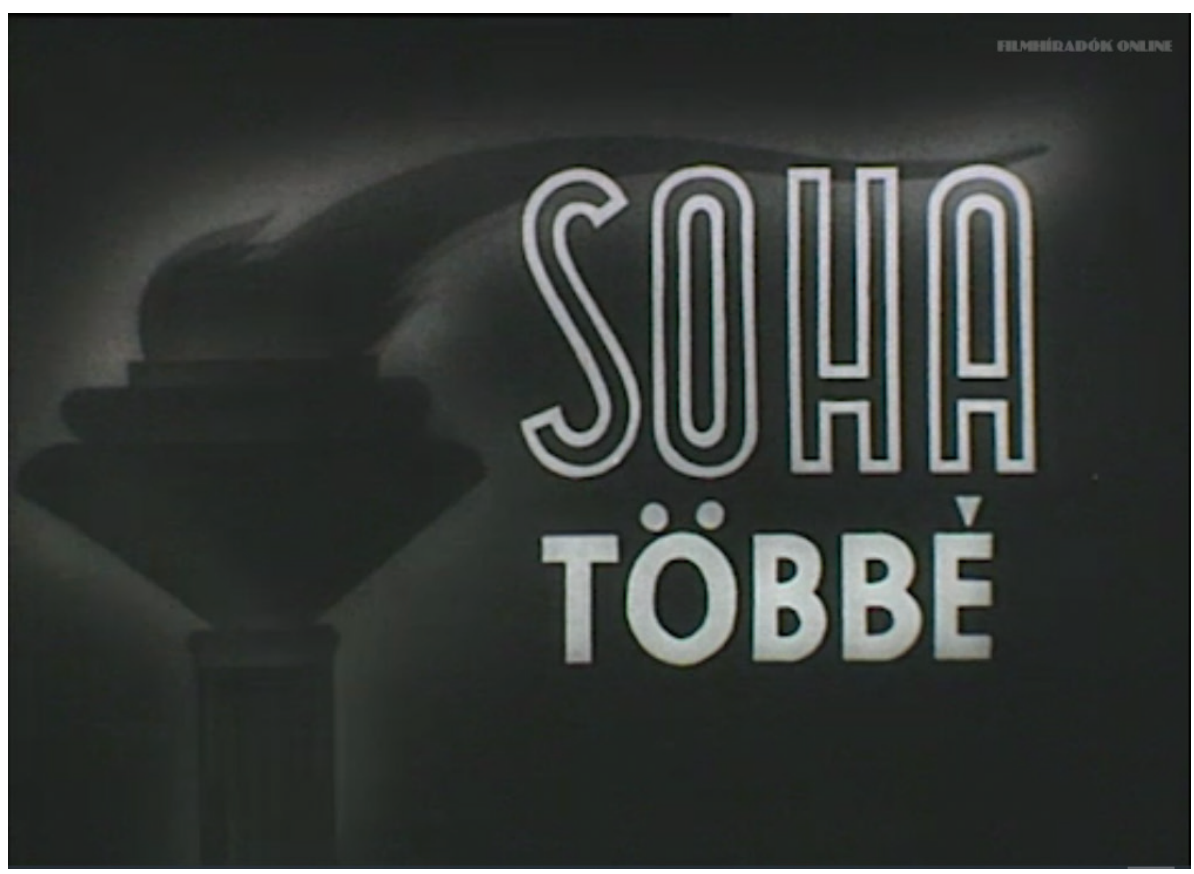

Video 1. Soha többé [Never again].

During the summer of 1956, people expressed their critical views about the state of affairs in the country. They openly debated the economic policy, the dismal performance of the agriculture, etc. The role and the situation of the press and the radio were debated in front of 6000 people. The growing disappointment and dissatisfaction in combination 
with anger over the unlawful acts committed during Rákosi's rule gradually increased the social unrest. Then, rather unexpectedly but understandably, a revolution erupted on 23 October 1956. The armed conflict gaining momentum on the evening of 23 October was directly related to the key media institution, the Hungarian Radio (and Television). The revolution swept away the former leaders and replaced them by an Executive Committee for the Television.

Afterwards, the Executive Committee directed and managed the Hungarian Television for eight months - although in a permanent political battle. The four-member Executive Committee definitively launched television broadcasting, elaborated its programme policy, working structure and main artistic and technical systems. By the fall of 1957 , however, all members of the Executive Committee, along with most other employees working together with the Executive Committee were removed from the institution under a reprisal process.

Thus, it is understandable that the process of establishing the Hungarian Television has not been researched and the real facts have not been publicly disclosed during the Kadar era. The available information about Hungarian television mostly pertained to the technical development of television. ${ }^{9}$ There were short remarks of the highlight performances of the first period, and then the authors jumped to the events after $1958 .{ }^{10}$ Only short paragraphs without names were devoted to that period by other authors. ${ }^{11}$ Recently published studies have dealt with some Hungarian television programmes which were, however, produced after 1963. ${ }^{12}$

\section{From the First Resolution to the Failure}

The earliest opportunity after World War II to initiate Hungarian television was in 1949. The companies RCA and EMI/ Marconi offered services to establish television in Hungary. ${ }^{13}$ The Hungarian government showed no interest. During the following two years, several reports informed the Hungarian leadership that construction of television systems was under way in the GDR, Czechoslovakia, Poland, and even in Bulgaria. Then the leadership realised that they were neglecting the establishment of a significant propaganda tool and - even more importantly - were falling behind other socialist countries. Thus, on 28 April 1952 it assembled a meeting under the guidance of Ernő Gerő, deputy prime minister, to discuss how to establish Hungarian television. The minutes of the meeting accompanied by a note from Gerő were sent to Rákosi. The party leader made an official proposal to the Secretariat of the Party to set up a committee for preparing television. The proposal was approved on 7 May 1952. ${ }^{14}$ The Secretariat's decision requested the creation of the committee within two weeks and ordered it to make a detailed proposal for the Hungarian Television in a month. The main reasons of creating television were enumerated in Gerő's note: ${ }^{15}$

- Television is closely connected to the development of the Hungarian telecommunication, including its military aspects

- "Television is a more perfect and comprehensive instrument of propaganda and people's education than radio"

- A television station "will allow covering the key areas of the country without being disturbed by the enemy"

- Television will bring a new source of income although at the beginning it requires investment.

The first sentence of the note also referred to another motive: "the issue of television has been asleep". Hungary is lagging behind the Soviet Union and other socialist countries. The Television Committee had three meetings, recommended study-tours to the Soviet Union, the GDR and Poland. They maintained that television equipment and transmission stations must be manufactured in Hungary.

The National Planning Office (NPO) in coordination with the Ministry of Transportation and Postal Service (MoT) and the Hungarian Radio Office presented the final proposal "on the issues of introducing a television radio system" in December $1952 .{ }^{16}$ According to the proposal, all the equipment should be manufactured in Hungary on the basis of the Sverdlovsk television station documentation. Television would begin its experimental broadcasting by 7 November 1954 and the start of its regular performance was set for March 1955. Live outdoor programmes would start by 1 December 1955. The operation and technical management would be performed by a Television Company to be 
established by January 1953. The Hungarian Radio Office should establish a separate Television Department for dealing with all the programmes, performances and their content. Overall responsibility is shared by the minister of Postal Service and the head of the Hungarian Radio Office.

Hungarian television was a political issue in four senses:

1. The highest political organ made the decision.

2. Without a thorough examination of the resources available, the political decision put under pressure all the companies and government institutions involved.

3. The Radio Office was tightly controlled and directed by the Agitation and Propaganda Department of the Party as well as the Information Office of the Ministerial Council. The chairman of the Hungarian Radio signed the proposal regarding the establishment of the Hungarian television in December 1952 and was assigned as one of the two supervisors of the establishment and operation of television. However, he was arrested and removed from the Radio Office in January 1953.

4. One of the key tasks for Hungarian television was formulated by Ernő Gerő in his note. Hungarian television should be the key instrument of political agitation and propaganda.

The NPO elaborated a budgetary proposal for Hungarian television. The overall costs were set at HUF 75.58 million for the period of 1953-56 and divided into four yearly portions. In the budget, there was no mention of the costs related to the studios, the future programmes, cameras, equipment for the outdoor live performances, etc. In order to correct this, the MoT elaborated a proposal on 3 March 1953 for the Ministerial Council. ${ }^{17}$ This included the construction of a transmitting station as well as a studio. It recommended finishing the construction by 30 November 1953. A meeting on 20 April 1953 in Gerő's office reaffirmed the tasks stemming from the December and January resolutions: a 100-watt station should be constructed in accordance with the forthcoming Soviet documentation. ${ }^{18}$

By 1953, the Hungarian government ran into a serious economic and social problem. Due to the excessive concentration of financial resources towards heavy industry, the real income of the workers decreased by more than 30 per cent between 1949 and 1953. Nagy initiated a new economic programme. The economic policy battle at the national level influenced the development of television in two ways. Television was not considered a way of increasing living standards and therefore no priority was attached to its development. On the other hand, it qualified as an industrial investment programme for which the finances should be curtailed. An investment proposal from the NPO was submitted for the Hungarian Television in January 1954. ${ }^{19}$ The proposal showed a debate between the two key institutions, the MoT and the NPO in respect to the financing of the television investment programme. The NPO suggested 68.78 million HUF while the MoT proposed 101.18 million HUF.

The government approved 139.5 million HUF for the investment. However, several problems were emerging. The Soviet documentation was delivered more than four months late. Then it became clear that the technology used in the Sverdlovsk television station was out of date. The picture tube developed in a Hungarian factory was too sensitive to disturbances and had to be replaced by a Blaupunkt tube in every Hungarian- made television set. The Orion factory started the production of 12-inch picture tubes, but it was too small and a change to a 17-inch tube was necessary. The transition took time and money. The Hungarian-made mobile unit was sent back to the factory for substantial repair. The new transmitter of 500-watt capacity proved to be a total failure and it was dismantled after a month. The biggest blow to the development of Hungarian television was that the finances approved by the government were not provided. The NPO did not support the establishment of television - although never opposed it openly. While the January 1954 government resolution approved 39.2 million HUF for the two ministries in the year 1955, the NPO in its budgetary proposal set only 10.75 million HUF. The new economic austerity programme reduced the industrial investment by 26 per cent across the board in Hungary. The financing of the television investment program was reduced by 73 per cent. Thus, the NPO played a very significant role in the failure of the development of Hungarian television.

Outside factors of a political nature exacerbated these technical and budgetary problems. Although the development of television in Eastern European countries was seen as an element in the Cold War competition, Hungary did not 
Péter Rajcsányi, The Process of Establishing the Hungarian Television

receive significant Soviet support in creating Hungarian television. There was a substantial delay in the delivery of the Soviet documentation on which Hungarian production was meant to be based. Measuring equipment was imported because it was needed to make decisions on the location of the television station, and the testing of television sets. The ambivalence about the import (and finally the refusal of the import for many years) obviously hindered the fast development of television. The reasons of rejecting Western imports were both political and financial but the more important part was the political one. The contradictions around the import issue pushed the final decision-making onto the highest level where the political motivation usually prevailed. International events also influenced the development of Hungarian Television. One of them was the decision of Bundesrepublik Deutschland to join NATO in 1954. As a result, the Soviet and the Hungarian leaderships again started to prioritise the development of heavy and military industry. Thus, the Hungarian economic policy again followed the Soviet course and neglected the development of television.

There were many domestic political reasons for the neglect of the television project. Mátyás Rákosi remained the first secretary of the Hungarian Worker's Party, and he initiated a hidden fight against Imre Nagy and his programs. There was an almost permanent debate about economic programs and not much attention was devoted to television. The development program for television did not have an appropriate high-level supervisor or coordinator for three years. Without the expected Soviet support, the burden of the development fell on the Hungarian experts and scientists, but Hungarian factories largely lacked experience with systems and equipment needed for a television network. So by early summer of 1955, it became clear that the establishment program of Hungarian Television run aground.

\section{Role of the Television Department and New Resolution}

The Television Department within the Hungarian Radio system was established only in March 1954. The delay was due to the changing and unstable situation after the removal of the previous Radio chairman. ${ }^{20}$ The new head was Dezső Révai, previously head of the Hungarian film company Hunnia between 1948 and $1953 .{ }^{21}$ The first action of the Television Department was to order a short movie on the results of Hungarian agriculture. It was to be shown on television sets in the Agricultural Exhibition in September 1954 together with other short films. ${ }^{22}$

The Nagy government established a new Information Office in order to counter the influence of the Party apparatus in the media. The Information Office held a meeting about the issue of television on November 16, 1954 and the Television Department drafted a new investment program. ${ }^{23}$ This proposed to import television equipment "from capitalist countries" and enumerated all the required equipment. The proposal also suggested the establishment of a microwave connection between the studio and key cultural and sport centres. It set December 311955 for the opening of television in Budapest. The proposal was submitted by the chairman of the Information Office to the Ministerial Council on February 22, 1955. It was, however, too late. In the Political Committee meetings, Rákosi was already openly requesting the removal of Imre Nagy from his position. In the political situation emerging by February 1955, the issue of television turned out to be irrelevant. The Ministerial Council decided at its February 22 meeting that it required a new proposal on television. A proposal elaborated by the MoT and sent to the Political Committee in early March met the same fate. ${ }^{24}$

The Information Office made yet another attempt to bring forward the television issue and submitted a report, describing the situation of Hungarian television. ${ }^{25}$ The report was very critical about the previous process of television development. It pointed out that "the time passed since the 1952 resolution did not bring the desired results." It also enumerated several mistakes and a number of defects: "the television committee was unable to fulfil its task," "under the pressure of the MoT the industry agreed upon deadlines the observance of which was baseless from the very beginning," "the operation and program creation were neglected." The report candidly judged the Soviet participation: "The equipment included in the Soviet documentation are no longer up-to-date 
and the Soviet Union does not produce them anymore. Moreover, the export of the equipment is prohibited". The report concluded that "the committee of experts finds appropriate the import of a modern Western model system". In the changing political climate, the proposal and the report had no effect. On April 24, 1955, the MDP Political Committee expelled Imre Nagy and revoked all his assignments. The Information Office was eliminated by Rákosi. Thus, again political action delayed the development of Hungarian Television by several months.

After the waves created by the political change had died down, television again became an issue for the leadership. Returning from his long sick-leave in late April 1955, Gerö immediately ordered the Department of Heavy Industry $(\mathrm{DHI})$ of the Ministerial Council to make a comprehensive report on television and wrote a letter to the Political Committee. ${ }^{26}$ The DHI provided its comprehensive report on the "State of affairs of Hungarian television" in May 1955. ${ }^{27}$ It recommended the accelerated development of television, emphasized the importation of the station and the most important equipment. It disapprovingly noted the stance of the KPM that "the purchase of a television system from Western countries is politically inadmissible". In an attachment to the proposal, the Television Department expressed its concern over the slow domestic production of the necessary equipment and their unsatisfactory quality. ${ }^{28}$ It explained that the television industry could not be developed without proper program broadcasting and that the sale and production rate of television sets was dependent on a high level of programming. Up to this point the Television Department had not played any significant role in decision-making. The preparatory work for the high-level decisions was controlled by the MoT and in the financial matters by the NPO. The power of those organisations was stronger than that of the Television Department. Despite the significant professional artistic and technical knowledge accumulated in the Television Department, the political leadership did not provide adequate support to the Television Department and its proposals were not considered equal to those of the ministries. An important factor in this situation was the fact that Gerö did not like Dezső Révai and never gave him the opportunity for a one-on-one meeting.

The final proposal was submitted to the Political Committee on May 9, $1955 .{ }^{29}$ It started with the statement that the task set in the December 1952 resolution was not implemented due to the delay in receiving the Soviet documentation and the shortage of the investment finances. It concluded that the NPO was unable to provide the needed investment. In the PC discussion, Gerö stated that "today television is the crucial decisive issue of the modernization of the Hungarian industry. In addition to the atomic energy, it is the main course." He again reinstated the problem of "lagging behind." The PC decided on the import of a station and assigned József Mekis, newly appointed deputy prime minister to supervise the development of television. The decision to allow the import of television equipment was a significant step in theory and opened the opportunity for Hungarian television to join the international trend. Much still depended on the practical implementation, production deadlines, the quality of the domestic and imported products and the finances available.

A full-fledged meeting attended by the representatives of all the institutions related to the development of Hungarian television was held on June 17, 1955. The results and suggestions of the meeting were summarized in a report and sent to the Political Committee. ${ }^{30}$ As the Soviet import was aborted, the deputy prime minister decided in September to import a 12-kilowatt station from Czechoslovakia. ${ }^{31}$ The Television Department, however, admonished the deputy prime minister in late August that the available Czechoslovak station was only a prototype and the consequences of any hidden fault might affect the Hungarian side..$^{32}$

On October 25, 1955 a new investment proposal was elaborated in Mekis's office with the help of the Television Department, the $\mathrm{DHI}$ and several experts to the Ministerial Council. ${ }^{33}$ The resulting new resolution was a fundamental change to the 1952 and 1954 resolutions - although it was called a modification. It can be seen as a completely new beginning and approach to television development. ${ }^{34}$ 


\begin{tabular}{|l|l|}
\hline Instrument/system & Investment sum (million HUF) \\
\hline 12 kilowatt station and import mobile unit & 5.72 \\
\hline 5 kilowatt station in Miskolc & 7.50 \\
\hline international microwave connection & 2.50 \\
\hline Budapest-Miskolc microwave connection & 7.00 \\
\hline television studio construction work & 14.50 \\
\hline studio and laboratory equipment & 6.00 \\
\hline studio equipment and projectors & 14.00 \\
\hline mobile units Hungarian made & 11.50 \\
\hline station tower construction in Budapest & 8.00 \\
\hline station construction in Miskolc & 3.00 \\
\hline planning etc. & 5.28 \\
\hline Total & 85.00 \\
\hline
\end{tabular}

Figure 1. New investment program for the Hungarian television (1955).

In accordance with the new resolution, a central station would be constructed in Budapest, a station in Miskolc, and studios would be constructed and fully equipped by the end of 1957 . Two mobile units would be made in Hungary and a mobile unit would be imported from Great Britain. Regarding costs, the resolution included a note that the investment plan was an estimate and the actual costs might vary by 15 per cent. There was no contingency source for the extra costs., Mekis informed the members of the Central Committee of the Party about the resolution while Gerö spoke about television in a speech in the Hungarian Parliament. ${ }^{35}$ Although Gerő's speech was rather detailed, he did not mention any previous mistakes or state that the former resolution was completely modified. All the previously mentioned reasons for the television development were enumerated in his speech: "Firstly, television is an extremely important, modern communication instrument: it significantly contributes to the education of our people in socialist spirit, to the distribution of theatrical and film culture, dance culture, sport, etc. From a cultural standpoint, television revolutionizes not only the urban life but also that of the villages. Television is of great significance for the development of our communication industry, or I may say that of our whole industry. It is a crucial tool for the defence, too. The implementation of television as well as the production and sale of television equipment is important for the increase of our living standards." However, by December 1955, it became evident that the Czechoslovak station was below the quality level required. The deputy prime minister decided for a 30-kilowatt station to be imported from the GDR with the assumption that it would be operable in September 1956.

\section{Work Plan for Television}

As the Ministerial Council had accepted the investment program, the Television Department could finalize its organization and make all the preparatory steps for broadcasting. The draft work plan for the year of 1956 was completed by late October under the guidance of Dezső Révai, head of the television Department and Ferenc Rajcsányi, ${ }^{36}$ head of the Production Department. ${ }^{37}$ It suggested the beginning of the broadcasting on January $1,1956$. However, the Radio Collegium approved the final version of the work plan only in February 1956: "the plan properly determines the tasks of television development". ${ }^{38}$ This caused a three-month delay. It is interesting that the plan was approved without significant discussion of its professional content. This may show that the plan was comprehensive and covered all the main areas of an expected television broadcast program. The remarks from the Collegium members mainly dealt with the relationship between the Television Department and radio, and tried to promote radio as a model for the television organisation. The only change in the plan related to the political control of television. While the plan suggested that the Radio Collegium exercised the control over the Television Department, Valéria Benke the president of Radio required the control position for herself and her request was approved by the Radio Collegium. "Television belongs to the Radio and operates under the direct control of the Radio president." 
P. Rajcsány, The Process of Establishing the Hungarian Television

The goal of the Television Department was to provide several hours of programming with colourful elements three days a week by the end of 1956. In the fourth quarter, the suggested total broadcast time, including sport events, would be about $140-150$ hours.

The work plan covered five main areas:

- film production

- outdoor live broadcasts

- the establishment of the Technical Department

- personnel issues

- $\quad$ working conditions for the Television Department

In respect to film production, the Television Department planned to produce 10 short films with artists and another dozen films with outstanding figures of Hungarian sport. It made steps to co-operate with the Hungarian film industry to produce 12 documentary films. The work plan also included the production of television commercials. Such a large-scale film production plan was obviously connected with the fact that Révai was the general director of Hunnia for years and Rajcsányi ${ }^{39}$ has had substantial experience in directing and producing movies. Several elements of the project resembled the American television practice: commercials on the television screen for income, extended co-operation with the film industry, international and domestic sale (and exchange) of short films made-for-television, and production of television documentaries. In Hungary, after 1948, the centre of movie film production was the nationalised Hunnia enterprise. Hunnia did not look at television as a rival as it was just a start-up enterprise. Knowing the close working relationship between American television companies and the big movie companies, the Television Department planned the involvement of Hunnia directors and professionals in the productions of short films for television. One of the young directors of Hunnia even made a proposal of his short films for television broadcast. ${ }^{40}$ The Television Department was ready to set up agreements with Hunnia about films for television and its own contribution to the production of theatre movies. In its work plan, the Television Department concluded that such co-operation agreements would be beneficial and profitable for both institutions. In 1956, in order to further improve the relationship between the Hunnia and the Television Department, the Hungarian Television celebrated the 25th anniversary of Hungarian sound-film production by broadcasting the Hunnia movie "Díszelöadás." 41 In early summer, the Television Department concluded an agreement about the broadcast of Hungarian movies with the nationwide distributor company, Mokép. The agreement was favourable for television as it ensured the broadcast of new premier Hungarian movies without any significant time delay. Within just two weeks in the first half of October, two brand new Hungarian movies were broadcast. ${ }^{42}$

Although the Television Department has had to wait months for the arrival of mobile units for outdoor live broadcasts, it concluded agreements with the National Committee for Sports and Physical Education to ensure access rights to the key sport events in Hungary. Next year the Executive Committee elected during the revolution utilized the agreement and first in April 1957, broadcast live a National Championship football match. It was also recorded by the movie Newsreel as a new achievement by the Television Department. 


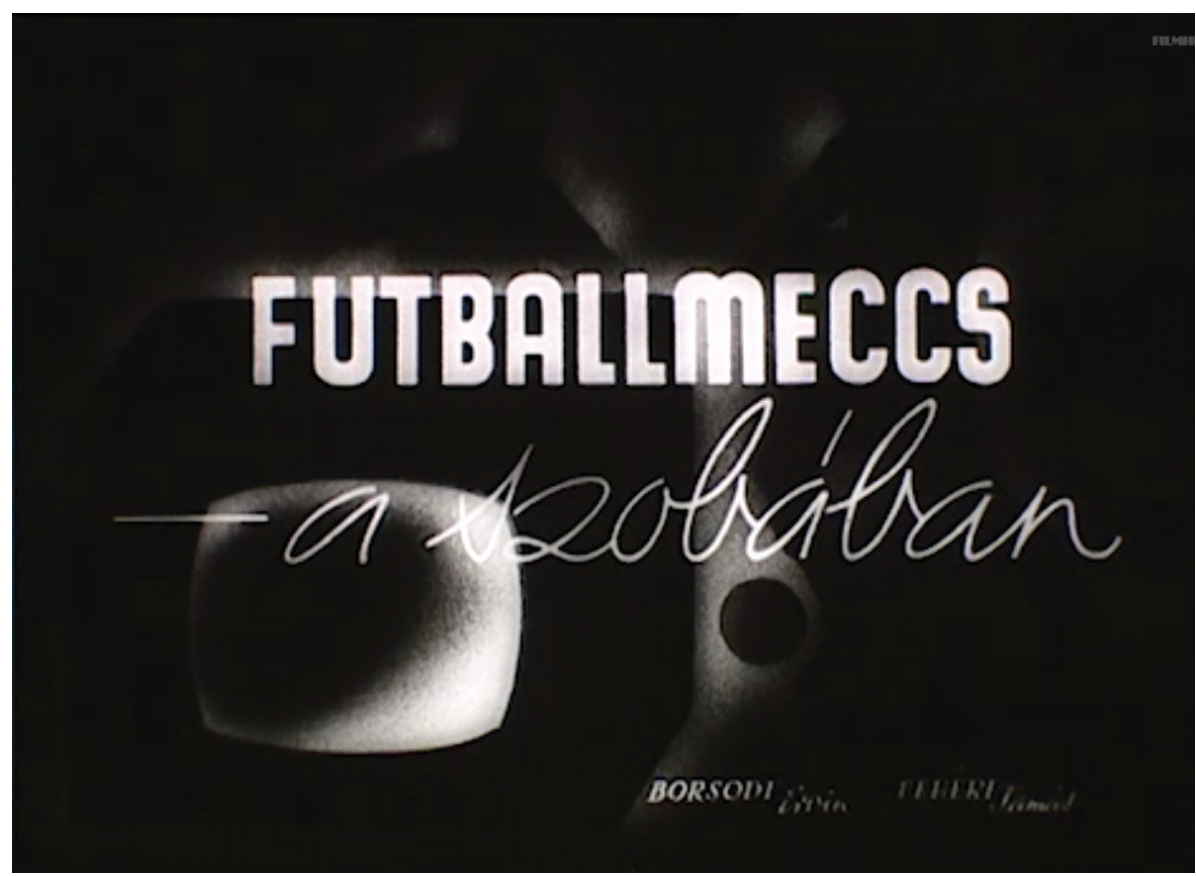

Video 2. Futballmeccs a szobában [Football match in the room], Magyar Filmhíradó (from 3,25 to 5,23 min).

It also negotiated with the Ministry of Public Education access to musical and theatrical performances in Hungary. The work plan also emphasized the rights of Hungarian television to freely set up contracts with actors and actresses for television films.

The work plan concluded that a Technical Department must be established that would take care of the operation of the newly acquired equipment and those soon to be transferred from the Television Company. The Television Department was also open to taking over the employees of the Television Company.

Regarding the personnel issues, the plan required 20 employees by the end of the first quarter of 1956 and 144 employees by the end of the year. Actually, by the end of October 1956, 29 professional and administrative persons as well as 20 technical experts worked in Hungarian Television Department. While the draft work plan emphasized the need for qualified employees with substantial experience in the film industry or in Radio, the Radio Collegium wanted young graduates from the Theatre and Film Arts High School, youngsters recently graduated in the Soviet Union and young technicians.

The working conditions of the Television Department had several problems. Although the deputy prime minister decided that a large part of the former Stock Exchange building would be available as the Television Department headquarters, the July resolution of the Political Committee approved the use of only a part of the building. ${ }^{43}$ However, the NPO did not want to provide 22.9 million HUF investment money. Thus, the hope of the Television Department that the building would be available for its purpose by September 1956 vanished quickly.

The work plan emphasized the need for internal educational courses about the technical and artistic requirements and specialties of television. In respect of issues of propaganda, it only stated that "The direct goals of the Party will be first of all served by programs of news communication and information service." 44 This did not completely correspond to the idea of the political leadership. In general, the work plan hinted at a program policy that covered the full scale of the television programs. The program structures of Hungarian Television are very similar to the West German ZDF established in 1963. 
Within Hungarian Television, there were four main departments: program, production, technical and economic departments. Until September 1956, only the head of the Production Department and the head of the Economic Department had been appointed. The organizational structure for the editorial work of television followed the Hungarian Radio structure. ${ }^{45}$

Television broadcasting became regular since April 1956. Twice a week, every Tuesday and Thursday from 19:30 to 22:00 the broadcast program included movies, short films, cartoons, sport news and newsreels. The 1-kilowatt station installed on May 1, 1956 improved the broadcast quality and substantially extended the area covered. The Hungarian movie Newsreel informed the public of the operation of the Television Department in June. ${ }^{46}$

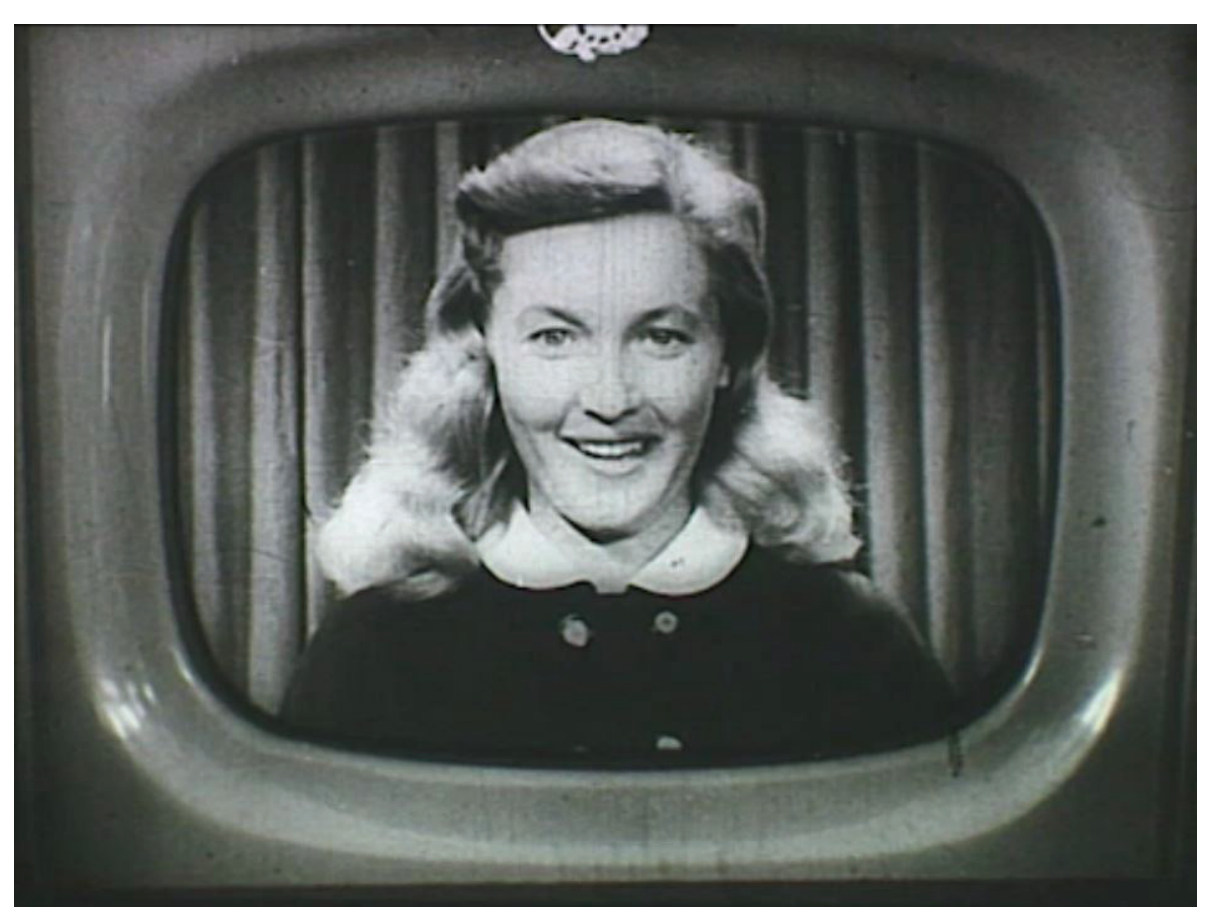

Video 3. Mi újság a televízióban? [What's news on television?] Magyar Filmhíradó 1956.23. (from 0,28 to 2.26 min)

The Television Department broadcast its previously produced short films and documentaries, including those with the world-known musicians, Zoltán Kodály and Aladár Rácz and a new interview with Yehudi Menuhin visiting musician friends in Budapest. A short film was made in an international youth camp at Lake Balaton as the first youth program. In September, the first entertainment program was broadcast which opened the way toward the production of different sorts of entertainment programs. Several short and portrait films were made with Hungarian athletes in training for the Melbourne Olympic Games. ${ }^{47}$ On October 2, 1956, a film was broadcast on swimmers preparing for the Olympic. A short film composition of the British-Hungarian swimming competition held in Blackpool on September 28-29 was broadcast on October 9. There were broadcasts of theatre pieces filmed in Hungarian theatres, too. From early October, the Television Department increased the weekly broadcast for three days.

By October 1956, the Hungarian Television Department made progress to produce a regular broadcast program, elaborated a program policy and program structure, and made the first successful steps on the system of newsreels, sport, scientific and entertainment programs. It had a small-scale organisation with several professional workers who gained their experience in the film industry or in radio and a few inexperienced, but politically "trustworthy" workers. The technical team was quite experienced. As a result of the four-year process, Hungarian television had a skeleton that needed fleshing-out and had a regular broadcast twice a week (Tuesday and Thursday). Its establishment suffered the influence of the Cold War mentality in several ways: import from Western countries was prohibited for 
years; there was no study trip to the advanced television companies in Great Britain, France or the United States (only to the Soviet Union and Eastern European socialist countries). Irrespective of the real results, the development of Hungarian television was highly praised by the political leaders in public speeches and the daily press as a symbol of technical progress and increasing standard of living. Its declared main goal was to serve as an efficient propaganda tool under the tight control of the political leadership.

It is probable that the political leadership had a certain ambivalence towards television. They wanted the desirable effects of television but feared the unknown and possibly embarrassing influence on the public. So the political leadership wanted television to be operational as soon as possible, saw it as part of the broader modernisation effort and was aware of its potential connections with the communication and the military industries. On the other hand, it did not provide adequate support to the Television Department in the bureaucratic fighting with the ministries and the NPO and did not fully provide the finances needed. Within the zigzags of the economic policy and television financing, the only "consistent" line was that of the NPO: it never provided "enough" money for the television project. The main reason for such behaviour was the deep conviction of the NPO leaders after 1949 that Hungary, above all, needed the fast build-up of the heavy military industry just as it happened in the Soviet Union. The new economic policy of the Nagy government in 1953-54 excluded television from its financial priorities. Throughout the four-year process, the Hungarian television project was underfinanced, even in the new investment program approved in October 1955.

This resulted in the inadequate number of cameras and other equipment, lack of studios, low quality of Hungarian-made equipment and an old building as headquarters that became too small for the television institution after a few months. The intended work plan became difficult to implement. The Television Department first made programmes which were seen as key elements: "home-made" short films, films and live broadcasts related to sport as well as Hungarian art and culture. Gradually, it moved on to broaden the program assortment and included entertainment programs, natural science educational programs, art films, newsreels and musical performances on film. In May and June 1956, it twice made successful efforts to establish connection to the Bratislava and the Wien (Kahlenberg) television stations for program transfer. In the latter case on June 21, the performance of the Hungarian State Folk Ensemble in Milan was received through the Austrian television channel, but only for a small audience. Excerpts from the Austria-Hungarian national team football match held in Wien were publicly broadcast on Hungarian Television mid-October 1956. During the event, the head of the Production Department of Hungarian Television had a chance to study the Austrian broadcast technique and methods and discussed establishing a permanent exchange program between the two. An in-principal decision was made in late 1955, but nothing more happened despite the multiple Austrian initiatives. Co-operation agreements with the GDR and the Czechoslovak televisions were already signed and talks started with the Yugoslav Radio (Television) Association in Budapest. The (mainly one-sided) unpaid exchange of movies, films of musical performances, cartoons and newsreels between the Hungarian television and the Soviet television was in place since the beginning of the Hungarian television broadcast. Occasionally, short films and brief news items from Western European television stations appeared on Hungarian television screens. Although the movie import for Hungary was completely controlled and censored by Hungarofilm, the selection of the movies for television broadcast was at the discretion of the Television Department which tried to maintain a balance between the Western and Eastern imported movies (but giving the higher percentage to the socialist import, set by the Political Committee). The frequent invitations of Hungarian artists, musicians and orchestras, ensembles to perform on television in many Western European countries opened a new channel of television co-operation and initiated a similar program idea in the Television Department. ${ }^{48}$

However, the whole system of the Hungarian Television was not complete. There was no studio with proper equipment, the Hungarian-made mobile unit did not work, the British mobile unit for outdoor live broadcasts has not arrived yet, some of the equipment for quick $16 \mathrm{~mm}$ newsreel filming were missing, the headquarters building was under reconstruction, the station tower was not completed and not equipped, and the number of qualified professionals in the organization was small. It still required a competent, professional management and personnel to turn television into a functional public service broadcast for entertaining and informing the Hungarian public. Such a management was elected as the Executive Committee ${ }^{49}$ of Hungarian Television during the 1956 October revolution and was assigned to determine the program policy and program structure, to re-establish and lead Hungarian Television. 


\section{Notes}

1 Timothy Havens, Aniko Imre, Katalin Lustyik, eds., Popular Television in Eastern Europe during and since Socialism (New York \& Oxon: Routledge, 2013).

2 Sabina Mihelj, "Understanding Socialist Television: Concepts, Objects, Methods," VIEW Journal of European Television History and Culture 3, no. 5 (June 2014): 7-16; Alexandru Matei and Annemarie Sorescu-Marinkovic, "The Exceptionalism of Romanian Socialist Television and its Implications," Panoptikum 20, no. 27 (2018): 168-192; Heather L. Gumbert, Envisioning Socialism: Television and the Cold War in the German Democratic Republic (Ann Arbor: University of Michigan Press, 2014).

3 Kirsten Bönker, Julia Obertreis, Sven Grampp, eds., Television Beyond and Across the Iron Curtain (Newcastle-upon-Tyne: Cambridge Scholar Publishing, 2016).

4 Dana Mustata, "Editorial," VIEW Journal of European Television History and Culture 3, no. 5 (June 2014): 1-6.

5 e.g. Teréz Vincze, "History on Hungarian Television: An introduction," in History on television in Seven East Europe countries ( ${ }^{\text {nd }}$ Research Report), eds. Luisa Cigognetti, Lorenza Servetti, Pierre Sorlin (II Filo d’Europa Vol. 5, 2011), $13-27$.

6 In order to turn Hungary into "a country of iron and steel" along the Soviet line, the government created a whole city (Sztálinváros - city of Stalin) as a centre of iron industry in 1949-1952. Another project was the subway construction in Budapest that imitated the Moscow metro to improve public transportation and to create safe shelters as the Moscow metro stations served during air-raids against Moscow. The plan was to build a combination of circular and radial lines a la the Moscow metro system. See István Rostássy, "A budapesti és a moszkvai metro tervéről" [About the plans of the Budapest and Moscow metros], Magyar-Szovjet Közgazdasági Szemle, 1951.1-12.sz., 503-513.

7 The term is used here in the sense of restoring somebody to good repute, or to a former capacity/position. During the early fifties, many Hungarians were sentenced in unlawful processes to jail, to concentration camps or to death. During the rehabilitation, those unlawful sentences were declared void in a legal court action, people were released from the jail or the camp, financially compensated and in some cases re-established in the same or similar capacity. The new actions were publicized or in some cases the rehabilitation included an official, open ceremony like in the case of the reburial of Rajk and his associates.

8 The film was a part of the official movie newsreel service: Magyar Filmhíradó 41, 1956 október.

9 János Koreny, Gábor Heckenast and András Polgár, A magyar televízió története [History of the Hungarian television] (Budapest: Ajtósi Dürer Kiadó, 1995).

10 Sugár Gusztáv, A néprádiótól a müholdas televízióig [From people’s radio to satellite television] (Budapest: Ajtósi Dürer Kiadó, 1993).

11 P. Dunavölgyi, MTV történet, www.filmesház.hu and László Babiczky, Szabadság tér 17 (Budapest: Ráday Könyvesház, 2007).

12 Aniko Imre, "Adventures in Early Socialist Television Edutainment, Journal of Popular Film and Television 40, no. 3 (2012): 119-130; Gergely Bokodi-Oláh, Megelevenedő történelem [Emerging history] (Budapest: MEK.OSZK, 2009); László András Palkó, "Az egyszemü szörny születése" [The birth of a cyclops], Valóság 54, no 8 (2011): 61-78.

13 A televízió kiépítésének ötéves terve (Five-year plan of the creation of television), Közlekedés és Postaügyi Minisztérium. IV/II. section, 1949 december 17, MTVA Archive, 44.box, TD-251/8

14 Televíziós bizottság létrehozása [Establishing a television commission], Határozati jegyzőkönyv, MDP KV Titkárság, 1952.05.07

15 Gerő Ernő feljegyzése Rákosi elvtársnak [Notes from Ernő Gerő to comrade Rákosi], MT GE 906/912, V.3, V.7., 1952.04.28

16 Előterjesztés a televíziós rádióadás bevezetésének kérdéseiről [Proposal on the issues of introducing a television radio system], Szigorúan Bizalmas [Top secret], Signed by Zoltán Vas, chairman, 15 December 1952, MDP KV Titkárság, MSZMP KB PI Irattár, 3257/52.XII.16.

17 Feljegyzés a Miniszter Tanácsi előterjesztéshez [Note to the proposal for the Ministerial Council] 1953.03.03. MNL XIX-A-2-ee dosszié, TÜK/1953.

18 Jegyzőkönyv a televíziós adás tárgyában Gerő Ernőnél tartott megbeszélésről [Minutes of the meeting on the television broadcasting held at Ernő Gerő's office] 1953 április 20, MNL G3516/TÜK/1953.

19 A Magyar Televízió beruházási programja [Investment program for the Hungarian Television], MT ülés 1954 január 15 és Határozat, 1954 január 29, MT 519/16/1954.

20 Written resolution on establishing the Television Department could not be found in the archives. The Secretariat of the Party decided to appoint Dezső Révai as the head of the Department on its session of March 19, 1954.

21 A Titkárság elfogadja Révai Dezső elvtársat a Magyar Rádió Televiziós Főosztálya vezetőjének [The Secretariat approves Dezső Révai as the head of the Television Department of the Hungarian Radio], MDP Titkárság, MNL, 276.f.54.0̋.e., 1954 március 19.

22 Ma nyílik meg a Mezőgazdasági Kiállítás [The Agricultural Exposition opens today], Magyar Nemzet, 1954.09.11

23 Előterjesztés és Révai Dezső levele [Proposal and letter from Dezső Révai], November 26, 1954, MTVA Archive, 47. box, TD-295/2. 
24 A magyar televízió megvalósítási programja [The implementation program of the Hungarian Television], Előterjesztés a Politikai Bizottsághoz [Proposal for the Political Committee], Szigorúan titkos [Top secret], signed by Lajos Bebrits, MNL 276.f.53.223.ő.e., 1955 március 31.

25 Tájékoztatási Hivatal feljegyzése Farkas Mihály részére [The implementation program of the Hungarian Television], 1955.03.28, MNL 276.f.53.cs.223.ő.e.1955.

26 Gerő Ernő levele, 1955 május 14, MNL MT G1169/55 and 86/Me/55.

27 Feljegyzés Gerő Ernő elvtárs részére, Tárgy: A magyar televízió helyzete [Note for comrade Ernő Gerő, Subject: The state-ofaffairs of the Hungarian Television], MT Titkárság Nehézipari Osztály (Signed by Papp and Máthé), 1955 május 3. MNL MT $\mathrm{G} / 1169 / 55$

28 Feljegyzés a Politikai Bizottság számára készülő előterjesztéshez csatolva. Aláíró: Révai Dezső, a Magyar Rádióhivatal televíziós főosztályvezetője [Note attached to the proposal for the Political Committee], 1955 április 18, Előterjesztés a Politikai Bizottsághoz, MNL V/620/55.V.25

29 Előterjesztés a Politikai Bizottsághoz [Proposal for the Political Committee], Tárgy: A magyar televízió megvalósítási programja [Subject: The implementation program of the Hungarian Television], Szigorúan titkos, [Top Secret], 1955 május 9, MNL V/620/55/V.25., M:18.91

30 Jelentés a Politikai Bizottság részére, A televízió megvalósítása [Report to the Political Committee, The implementation of the Television], MNL MT 86-8/Me, 1955 június 21

31 Mekis levele Bebritsnek, 1955 szeptember 8, MNL XIX-A-2-kk., Televíziós ügyek 1955-1-956, 10. doboz.8.dok.

32 A televízió szervezeti kérdéseiről [On the organisational issues of the Television Department], Televíziós Főosztály, 1955 augusztus 29, MTVA Irattár, 19. doboz, TD-315/10

33 Előterjesztés a Miniszter Tanácshoz. A Magyar televíziónak a II. ötéves tervben végrehajtandó beruházási programja [Proposal for the Ministerial Council, The investment program of the Hungarian Television during the 2nd five-year plan), 1955 október 25, MNL MT 86/25 és MTVA Archive, TÜK, 6. doboz. TD- 266/5, 00121/1955 október 22.

34 Az 519/16/1954 sz. határozat módosítása a magyar televízió beruházási programjáról [Modification of the resolution 519/16/1954 for the investment program of the Hungarian television], MT határozat 4511/1955(XI.3.), B-1148/TÜK/1955.

35 Az Országgyűlés elfogadta az 1956. évi népgazdasági tervet, Gerő Ernő beszéde [The Parliament accepted the national economic plan for 1956], Szabad Nép, November 18, 1955.

36 On the recommendation of the Information Office, Ferenc Rajcsányi was employed as the head of the Production Department by 1 st of October 1955 after he produced two short films in April and May for the Hungarian Television.

37 Javaslatok, Televíziós Főosztály, 1955 október 29, MTVA Irattár, 20. doboz, TD-316/7 és MNL XIX-A-2-kk, Televíziós ügyek 1955-56, 10. doboz, 326 ej.

38 A Televíziós Főosztály 1956. évi munkaterve [Work plan of the Television Department for 1956], MTVA Irattár, 20. doboz, TD-316/4 és a Rádió Kollégium határozata, 1956 február 26, MTVA Irattár, 20. doboz, TD-316/5.

39 Ferenc Rajcsanyi worked as production manager and assistant director in the films Ének a búzamezökröl (1947), Emberek a havason (1942), Valamit visz a víz (1944) and in several other productions.

40 Banovich's films showed Hungarian folk dances (csárdás) and were on the screen a few times. The last occasion was in October 1956, Drágszéli Csárdás és Régi Csárdások, Magyar Televízió müsora, Magyar Nemzet, 1956.október 2.

41 The election of the Executive Committee in the Television and a Workers Council in the Hunnia during the 1956 October revolution gave even a better chance for the co-operation because of the long and close personal friendly relationship between the chairman of the Executive Committee and the members of the Workers Council. After the elimination of the Executive Committee and the Workers Council during the 1957 reprisal, the relationship between the two institutions cooled down and became more "institutional". Real co-production did not occur later.

42 Tanár úr kérem, Magyar Nemzet, 1956 október 6, and Hannibál tanár úr, Magyar Nemzet, 1956 október 18.

43 Előterjesztés a Politikai Bizottság számára a televízió elhelyezéséről, 1955.07.22, MNL 276.f.53.cs.242.ő.e., 1955/07/28

44 A Televíziós Főosztály 1956. évi munkaterve, MTVA Irattár, 20. doboz., TD-316/4, p.2.

45 A televízió szervezeti kérdéseiről, Televíziós Főosztály [About organizational issues of the television], 1955 augusztus 29, MTVA Irattár, 19. doboz, TD-315/0

46 Mi újság a televízióban? [What's news on television?], Magyar Filmhíradó, 1956/23, 1956 június

47 Unfortunately, the films were not archived and lost during the next years.

48 The idea could be realised only in the first half of 1957 when among others Yves Montand, Roberto Benzi, Lucienne Boyer and Soviet ensembles appeared in the Hungarian Television.

49 The eight-month activity and results of the Executive Committee are shown and analysed in Péter Rajcsányi, "A Magyar Televízió Intéző Bizottsága 1956-1957 - Elhallgatott Tények" [The Executive Committee of the Hungarian Television 19561957 - Facts held back], Történelmi Szemle 61, no. 3 (2019): 509-538. 


\section{B i o graph y}

Péter Rajcsányi graduated from the Technical University of Budapest as a chemical engineer-economist. Later studied history and international politics and joined the Institute of Foreign Relations of the Ministry of Foreign Affairs. He was head of department dealing with the United States, Canada and Great Britain. Then he served as adviser on international relations and lectured at Budapest universities. In 1991-1992, he was director of the Hungarian State Privatisation Agency. For several years, he was European director of an American company. Between 2005-2015, he was marketing and public relations director of FIDE. Recently, he conducts research work in association with the institutes of foreign relations as well as historical science and lecture in a Budapest university. 